\title{
Emergencia pública, presidencialismo y Estado de Derecho en Argentina en el contexto del
}

COVID-19

Public Emergency, Presidentialism and Rule of Law in Argentina in the context of the COVID-19

Autor: Cristian Altavilla

DOI: https://doi.org/10.19053/16923936.v18.n36.2020.12163

Para citar este artículo:

Atlavilla, C. (2020). Emergencia pública, presidencialismo y Estado de Derecho en Argentina en el contexto del COVID-19. Derecho y Realidad, 18,

(36), 181- 202 . 


\section{EMERGENCIA PÚBLICA, PRESIDENCIALISMO Y ESTADO DE DERECHO EN ARGENTINA EN EL CONTEXTO DEL COVID-19*}

Public Emergency, Presidentialism and Rule of Law in Argentina in the context of the COVID-19

Emergência pública, presidencialismo e estado de direito na Argentina no contexto do COVID-19

\section{Cristian Altavilla ${ }^{a}$}

cristianaltavilla@hotmail.com

\section{RESUMEN}

La pandemia generada por el COVID-19 activó los resortes institucionales previstos por la Constitución argentina para enfrentar emergencias públicas. Sin embargo, la magnitud e impacto de la situación generada por la pandemia del COVID-19 superó y excedió cualquier previsión legal y/o constitucional. La emergencia sanitaria puso de resalto una serie de problemas tanto sociales, políticos y económicos, como del propio diseño institucional del sistema constitucional argentino. El objetivo del presente trabajo es analizar el rol de los poderes del Estado Argentino en esta situación extraordinaria de emergencia pública sanitaria y su desempeño en el mismo, a través de una mirada crítica sobre su actuación, para examinar si se ha desarrollado en el marco de legalidad establecido por el régimen constitucional, o si bien ha estado al margen de dicha legalidad.

\begin{abstract}
La República Argentina comparte con sus hermanas naciones latinoamericanas el fenómeno denominado "hiperpresidencialismo", manifestado en la gran cantidad de atribuciones (de hecho y de derecho) que ejerce el presidente de la nación, como encargado del poder ejecutivo, situación que termina por generar un peligroso desequilibrio de poderes que atenta contra el sistema democrático y republicano. La pandemia, en este sentido, no hizo más que poner de resalto esta anomalía del sistema constitucional.
\end{abstract}

\section{PALABRAS CLAVES}

Pandemia; emergencia pública; COVID-19; constitución argentina; régimen constituciona; legalidad;

* Artículo de reflexión.

a. Abogado, Doctor en Derecho y Ciencias Sociales por la Universidad Nacional de Córdoba, Argentina; Director de la carrera de Abogacía, Universidad Siglo 21 (UES21) ), Córdoba, Argentina; Profesor de la materia Derecho Constitucional, de Derecho Público Provincial y Municipal y de Derecho Político, Facultad de Derecho - Universidad Nacional de Córdoba y de la UES21. Investigador en CONICET (2020). 
hiperpresidencialismo; desequilibrio de poderes.

\begin{abstract}
The pandemic generated by the COVID-19 activated the institutional levers included in the Argentine Constitution to face public emergencies. However, the magnitude and impact of the situation generated by the COVID-19 pandemic surpassed and exceeded any legal and/or constitutional provision. The health emergency highlighted a series of problems, social, political and economic, as well as issues related to the institutional design of the Argentine constitutional system. The aim of this paper is to analyze the role of the Argentine State powers in this extraordinary situation of public health emergency and their performance in it, through a critical look at their performance, in order to examine whether it has been developed within the framework of legality established by the constitutional regime, or whether it has been outside such legality.
\end{abstract}

The Argentine Republic shares with its Latin American sister nations the phenomenon known as "hyperpresidentialism", manifested in the great number of powers (de facto and de jure) exercised by the President of the Nation, as the person in charge of the executive power, creating a situation that ends up generating a dangerous imbalance of powers that threatens the democratic and republican system. The pandemic, in this sense, only highlighted this anomaly of the constitutional system.

\section{KEYWORDS}

Pandemic; public emergency; COVID-19; constitution; constitutional regime; legality; hyper-presidentialism; imbalance of powers.

\section{RESUMO}

A pandemia gerada pela COVID-19 ativou as fontes institucionais da Constituição argentina para fazer frente às emergências públicas. No entanto, a magnitude e o impacto da situação gerada pela pandemia
COVID-19 excedeu qualquer previsão legal e / ou constitucional. A emergência sanitária evidenciou uma série de problemas sociais, políticos e econômicos, bem como o desenho institucional do sistema constitucional argentino. 0 objetivo deste trabalho é analisar o papel dos poderes do Estado argentino nesta situação extraordinária de emergência de saúde pública e sua atuação nesta situação, através de um olhar crítico sobre sua atuação, para examinar se tem se desenvolvido no âmbito do legalidade estabelecida pelo regime constitucional, ou embora tenha estado fora dessa legalidade.

A República Argentina compartilha com suas nações irmãs latino-americanas o fenômeno denominado "hiperpresidencialismo", manifestado no grande número de poderes (de fato e de direito) exercidos pelo presidente da nação, como a cargo do Poder Executivo, situação que acaba gerando um perigoso desequilíbrio de poderes que ameaça o sistema democrático e republicano. A pandemia, nesse sentido, nada mais fez do que evidenciar essa anomalia no sistema constitucional.

\section{PALAVRAS CHAVE}

Pandemia; emergência pública; COVID-19; Constituição Argentina; regime constitucional, legalidade; hiperpresidencialismo; desequilíbrio de poderes.

\section{LA PANDEMIA DEL COVID-19 EN ARGENTINA}

El primer caso de COVID-19 en Argentina se registró el 3 de marzo de $2020^{1}$. Desde entonces, las autoridades públicas comenzaron a implementar distintas medidas para evitar la propagación del

\footnotetext{
1.https://www.perfil.com/noticias/coronavirus/ pandemia-COVID19-cronologia-del-coronavirus-enargentina-tiempo-real.phtml. Al 12 de julio de 2020, se registran en el país 100.166 personas afectadas por el virus, (55.627 infectados activos y 42.694 recuperados) y 1.845 fallecidos (La Nación, "La evolución de la pandemia en la Argentina", domingo 12 de Julio de 2020, disponible en: https://www.lanacion.com.ar/sociedad/ en-detalle-infectados-fallecidos-coronavirus-argentinanid2350330\#/).
} 
virus. En un primer momento, se ordenó la auto-cuarentena de aquellas personas provenientes de países afectados por el coronavirus (fundamentalmente EEUU y Europa); luego se decretó la feria administrativa y la suspensión de clases, hasta que finalmente se ordenó el Aislamiento Social Preventivo y Obligatorio, por el que se suspendía todo tipo de actividades (salvo aquellas consideradas indispensables) y se prohibía a todas las personas no exceptuadas salir de sus hogares.

Inicialmente, la región del país más afectada del país fue el denominado AMBA, que incluye la ciudad de Buenos Aires y el conurbano bonaerense (unos 40 municipios que pertenecen a la Provincia de Buenos Aires): una extensa zona metropolitana que concentra 14.800 .000 de personas, es decir, el $37 \%$ de la población Argentina. Por ello, los primeros esfuerzos se concentraron en esta región del país, que comprende la capital y sus alrededores. A pesar de todas las medidas implementadas para evitar la propagación del virus, comenzaron a surgir casos y a aumentar de manera crítica el número de contagios en otras partes del país, como en Mendoza, Córdoba, Salta, Tierra del Fuego y la Provincia del Chaco.

El nivel de contagios en los primeros meses de la cuarentena fue muy bajo. Recién hacia finales de mayo se llegó a los 500 contagios por día. A partir del mes de junio la curva comenzó a elevarse hasta llegar a picos máximos de 13.000 contagios por día, hacia fines de septiembre. En junio se alcanzó un pico de 3.000 contagios por día, en julio de 6.000 y en agosto de 11.700. Al 26 de septiembre, se informaron 702.484 personas afectadas (130.452 infectados activos y 556.489 recuperados) y 15.543 personas fallecidas ${ }^{2}$.

Comparado con otros países del mundo, Argentina (con 44.560.000 de habitantes) posee una tasa bastante alta de contagios y de muertes. De acuerdo con el número

2. Ver "La evolución de la pandemia en la Argentina", Diario La Nación, https://www.lanacion.com.ar/ sociedad/en-detalle-infectados-fallecidos-coronavirusargentina-nid2350330\#/, consultado el 27/09/2020. total de contagiados, Argentina se posiciona novena ${ }^{3}$, y $14^{\mathrm{a}}$ por cantidad de muertos cada 100.000 habitantes $^{4}$.

\section{ALGUNAS CONSIDERACIONES PRELIMINARES SOBRE EL SISTEMA PRESIDENCIALISTA ARGENTINO}

El artículo $1^{\circ}$ de la Constitución Nacional (en adelante $\mathrm{CN}$ ) establece que "La Nación argentina adopta para su gobierno la forma representativa republicana federal, según establece la presente Constitución". Este art. $1^{\circ}$ no menciona la adaptación de un sistema presidencialista, pero surge de la estructura institucional.

Los tres poderes que conforman el Estado Federal Argentino son el Poder Ejecutivo Nacional, ejercido por un ciudadano con el título de "presidente de la Nación Argentina" (art. 87, CN), con un mandato de 4 años con posibilidad de reelección inmediata por un período consecutivo más; el Congreso de la Nación, compuesto por dos cámaras, la de diputados (que representa al pueblo de la nación) y la de senadores (que representa a las provincias); y un poder judicial, integrado por la Corte Suprema de Justicia de la Nación (CSJN) a la cabeza del mismo y los demás tribunales inferiores (cámaras federales y juzgados federales de primera instancia repartidos en todo el territorio nacional).

Argentina, al ser un país federal, replica esta misma estructura a nivel provincial. Cada una de las 23 provincias y la Ciudad Autónoma de Buenos Aires (CABA) tienen su poder ejecutivo ejercido por un gobernador (jefe de gobierno es la designación que recibe en CABA), poderes legislativos (denominados generalmente legislatura

3. Detrás de Estados Unidos (7.101.774 casos), India (5.992.532), Brasil (4.717.991), Rusia (1.146.273), Colombia (806.038), Perú (800.142), México (726.431), España (716.481), Argentina (702.484).

4. España $(66,74)$, Ecuador $(66,02)$, Reino Unido $(63,18)$, Estados Unidos $(62,63)$, México $(60,42)$, Italia $(59,31)$, Suecia $(57,79)$, Panamá $(55,66)$, Colombia $(50,95)$, Moldavia $(47,56)$, Francia $(47,37)$, Países Bajos $(37,23)$, Irlanda $(37,02)$, Argentina $(34,93)$. 
provincial) y un poder judicial (encabezados por los Superiores Tribunales provinciales).

Con respecto al presidente, y de acuerdo a la estructura que le confiere la propia $\mathrm{CN}$, se le atribuyen las siguientes características: (a) es unipersonal, (b) es permanente y oficioso (en cuanto su actividad posee continuidad, no existen recesos en su tarea - a diferencia de los otros dos poderes, respecto del Congreso, que tiene fijado un período de sesiones, y del Poder Judicial, que sólo actúa a requerimiento de parte); y (c) está sujeto a los principios de supremacía y funcionalidad (cooperación entre poderes y control recíproco entre estos) (Quiroga Lavié, 2009: 1151-1152).

En Argentina, el fenómeno del presidencialismo y del hiperpresidencialismo se ha ido acentuando a lo largo de los años. Resulta interesante observar que este fenómeno se ha desarrollado y afianzado tanto en los hechos como en el propio diseño institucional: "[a]sí, a la considerable masa de atribuciones que le reconocía la Constitución de 1853/60, se sumaron prácticas que, oriundas en el período colonial, implicaron una fuerte concentración de potestades en manos del titular del Ejecutivo" (Carnota y Maraniello 2008: 221).

Más aún, puede notarse que el diseño constitucional dota al Ejecutivo de ciertas herramientas que reafirman su figura protagónica en el escenario político, siendo además esta una característica típica de los países latinoamericanos (Negretto, 2013; Gargarella, 2014): "Desde las primeras constituciones nacionales en América Latina, el diseño constitucional estuvo orientado a moldear una figura ejecutiva fuerte, con herramientas suficientes incluso para sobreponerse por sobre el Poder Legislativo" (Altavilla 2019:84).

El padre de la constitución argentina, Juan Bautista Alberdi, determinó muy claramente en su obra Bases y Puntos de Partida para la Organización Política de la República Argentina, publicada en 1852, que el destino de América Latina estaba en manos del Poder Ejecutivo: "yo no vacilaría en asegurar que de la constitución del Poder Ejecutivo, especialmente, depende la suerte de los Estados de la América del Sur", y más adelante agrega: "dad al Poder Ejecutivo el poder posible, pero dádselo por medio de una constitución", y trae a colación el caso chileno: "La paz de Chile [...] viene de su Constitución [y la] ha [logrado] por medio de un poder ejecutivo vigoroso, es decir, de un poderoso guardián del orden" (Alberdi [1852] 1994: 182).

Esta tendencia también puede verse en la última reforma constitucional. Desde el punto de vista normativo, la convención del 94 tuvo entre sus objetivos la "atenuación del sistema presidencialista", tal como establece el Núcleo de coincidencias básicas contenido en la Ley №24.309 (1993) de Declaración de la necesidad de su reforma. En este sentido, la reforma introdujo la figura del Jefe de Gabinete de Ministros (art. 100, CN), y reguló los poderes excepcionales del presidente, la delegación legislativa (art. 76, CN) y los Decretos de Necesidad y Urgencia (art. 93, inc. $3^{\circ}$ ). Sin embargo, la práctica posterior mostró ineficientes estas medidas, y la figura presidencial se fue concentrando cada vez más, por lo que algunos autores consideran que de hecho la reforma del '94 terminó por fortalecer aún más al presidente, tanto desde lo formal (con la posibilidad de reelección inmediata y por el sistema de voto directo) y desde lo material (con la incorporación de la delegación legislativa, los DNU y la promulgación parcial de leyes) (Carnota y Maraniello 2008: 221, en igual sentido, Badeni 2006, Sagüés 2017).

La expansión de los poderes del presidente en las repúblicas modernas comienza a hacerse patente hacia mediados del siglo XX, cuando se observa un ensanchamiento de las atribuciones clásicamente reconocidas al ejecutivo, la que se da en detrimento de los otros dos poderes, legislativo y judicial (Badeni 2006:1631-2). Sumado a ello, la mayor intervención de los Estados modernos en el ámbito económico y el manejo de las relaciones internacionales terminaron por afianzar la figura presidencial como el actor predominante dentro del sistema político. Esta hipertrofia 
en las funciones del presidente ha sido habitualmente señalada como causante de las crisis de gobernabilidad en la región y en particular en Argentina. Lo cierto es que esta concentración de poderes en uno solo de los órganos del Estado desbalancea el equilibrio de poderes que la Constitución busca y finalmente, pone en riesgo no sólo el sistema republicano en sí, sino también el régimen democrático.

Desde el punto de visto politológico, existen tres factores que empañan la naturaleza democrática del sistema argentino: "la limitada autonomía provincial frente al gobierno central, la cooptación del Poder Judicial por parte del presidente, y el uso de decretos ejecutivos de necesidad y urgencia por parte del presidente para pasar por encima del Congreso" (Jones 1998:237). Como puede observarse, de los tres factores dos se vinculan directamente con el fenómeno del hiperpresidencialismo (aunque el primero también, de modo más indirecto). A estos fenómenos hay que sumarles el poder partidario de los presidentes en Argentina, los que, desde 1983, han sido un factor decisivo para el fortalecimiento del poder ejecutivo en el país.

En todo el contexto político e institucional mencionado, el factor económico ha jugado un rol crucial. De hecho, el argumento que casi siempre se utiliza para justificar el acrecentamiento de los poderes del presidente ha sido la emergencia pública y prácticamente todo el siglo XX ha estado signado por la emergencia pública, en la mayoría de los casos, de naturaleza económica. Lo anterior llevó a una mayor concentración de poderes en manos del ejecutivo, visto siempre como la figura fuerte, ágil y eficiente para poder sortear los efectos de las crisis.

\section{LOS PODERES DEL PRESIDENTE EN LA EMERGENCIA. EL HIPERPRESIDENCIALISMO ARGENTINO EN EL DISEÑO Y EN LA PRAXIS CONSTITUCIONALES}

La constitución argentina no define la emergencia, y contiene algunas disposiciones aisladas al respecto. La emergencia es una situación excepcional, anormal o crítica, se trata de una circunstancia de hecho que cambia y trastoca el normal desenvolvimiento de las cosas y de las instituciones: "emergencia constitucional es la situación fáctica grave y extraordinaria por la que pasa la sociedad en la cual la Constitución, en alguna de sus partes, no puede funcionar plenamente al no presentarse los supuestos de hecho sobre los que dicho orden descansa, $y$, por ende, como ha dicho la Corte federal, los acontecimientos extraordinarios reclaman remedios también extraordinarios (F. 238:76)" (Quiroga Lavié, 2009:788).

El derecho constitucional argentino
diferencia las emergencias como acontecimientos reales - tales como la guerra, los desórdenes domésticos, las crisis económicas, etc.) - y los institutos de emergencia - el estado de guerra, el estado de sitio, la ley marcial, la suspensión de garantías, los remedios innominados (Bidart Campos, 2018:203). En el texto de la Constitución se mencionan como situaciones fácticas de emergencia a la guerra (cuando habla de "ataque exterior" en los arts. 23, 61 y 99 inc. 16 y de "invasiones exteriores" en el art. $6^{\circ}$ ) y a la conmoción interna ("conmoción interior" en los arts. 23, 75 inc. 29, y 99, inc. 16) (Bidart Campos, 2018).

En cuanto a los institutos de emergencia, la Constitución solo prevé expresamente cuatro:

1. La intervención federal (art. 6);

2. El estado de sitio (art. 23);

3. La delegación legislativa (art. 76); y

4. Los decretos de necesidad y urgencia (art. 99 inc. 3).

A ellos se puede añadir uno implícito, según Bidart Campos: el "estado de guerra", que surge de las competencias previstas para el Congreso en el art. 75 , inc. 25 y para el ejecutivo, en el art. 99, inc. 15. Aún así, en este caso, la Constitución no contiene ninguna disposición que expresamente autorice la ampliación de las facultades constitucionales 
de los poderes del Estado (Quiroga Lavié 2009:789).

La mayoría de estos institutos de emergencia fueron utilizados para afrontar situaciones críticas de naturaleza económica, principalmente. Argentina no ha atravesado gran cantidad de guerras o enfrentamientos armados con potencias extranjeras que llevaran a la utilización de estos mecanismos ${ }^{5}$.

El Estado de sitio está previsto en el artículo 23 de la Constitución Nacional, que dispone que "en caso de conmoción interior o de ataque exterior que pongan en peligro el ejercicio de esta Constitución y de las autoridades creada por ella, se declarará en estado de sitio la provincia o territorio en donde exista la perturbación del orden". Este instituto fue aplicado en cuatro oportunidades desde la vuelta a la democracia en 1983, y ha sido utilizado en cuatro oportunidades: el 25 de octubre de 1985 (en todo el país y por 60 días, levantado por el presidente en diciembre del mismo año) y el 29 de mayo de 1989 (en todo el país y por 60 días, aunque duró seis) durante la presidencia de Alfonsín; el 3 diciembre de 1990 (en todo el país y sin plazo, aunque la ley aprobatoria del Congreso le fijó un plazo fijo de 60 días y fue levantado por el presidente al día siguiente de su aprobación, el 4 de diciembre) durante la primera presidencia de Menem; y el 19 de diciembre de 2001 durante la presidencia de De la Rúa (en todo el territorio nacional y por treinta días, aunque lo levantó al día siguiente de decretarlo, como uno de los últimos actos de gobierno previo a su renuncia) (Altavilla 2016).

En los casos de 1985 y de 1990 se decretó el estado de sitio frente a una amenaza de golpe cívico-militar, y ante un alzamiento militar efectivo llevado a cabo por un grupo

5. Si bien Argentina estuvo en la Guerra contra Gran Bretaña en 1982 por la disputa territorial sobre las islas Malvinas, esta contienda bélica se desarrolló en el espacio marítimo del sur del Mar Argentino, y no en territorio continental; además, el país se encontraba bajo un gobierno militar de facto, por lo que no estaba vigente la Constitución. sedicioso denominados "carapintada", comandado por el entonces coronel Mohamed Alí Sineldín.

La intervención federal es aplicada como medida (de auxilio o de castigo, dependiendo de las causales que la habilitan) para garantizar en las provincias el ejercicio efectivo de su autonomía y la forma republicana de gobierno. Tiene su antecedente en la guarantee clause de la Constitución Norteamericana (Artículo IV, Sección 4), aunque con modalidades propias. La Constitución Nacional argentina la prevé en el art. 6, disponiendo que "el Gobierno federal interviene en el territorio de las provincias para garantizar la forma republicana de gobierno, o repeler invasiones exteriores, y a requisición de sus autoridades constituidas para sostenerlas o restablecerlas, si hubiesen sido depuestas por la sedición, o por invasión de otra provincia”. La intervención federal también fue utilizada en varias oportunidades desde el retorno a la democracia en 1983: durante la presidencia de Carlos Menem (19891999) se intervinieron las provincias de Catamarca (por DNU № 712/91, del 17/04/1991), Tucumán (por DNU № 103/91 del 15/01/1991), Corrientes (en 1992 por DNU $\mathrm{N}^{\circ} 241$, del 04/02/1992 y DNU № $1.447 / 92$, del 12/08/1992) y Santiago del Estero (en 1993). Durante la presidencia de Fernando de la Rúa (1999-2001) se intervino una sola provincia, Corrientes, mediante Ley del Congreso, $\mathrm{N}^{\circ} 25.236$ del 16/12/1999) y, finalmente, durante la presidencia de Néstor Kirchner (2003-2007) fue intervenida la provincia de Santiago del Estero (también mediante ley del Congreso, № 25.881, del 01/04/2004). Con anterioridad a 1983 (excluyendo los períodos de facto), el instituto de la intervención federal fue excesivamente utilizado por los presidentes, de manera abusiva y discrecional.

Por su parte, tanto la delegación legislativa (art. 76, CN), como los Decretos de Necesidad y Urgencia (art. 99 inc. 3, CN), fueron utilizados con mucha más asiduidad, lo que acentúa la predominancia del poder ejecutivo nacional en el sistema políticoconstitucional argentino, justificados 
- en la gran mayoría de los casos - por la emergencia pública. De lo anterior deriva la predominancia del poder ejecutivo nacional en el sistema político-constitucional argentino.

De acuerdo a la jurisprudencia de la Corte, hay cuatro condiciones mínimas para la determinar la validez constitucional de los institutos y las medidas de emergencia: (1) una situación real de emergencia, declarada o comprobada, (2) un fin real de interés social y público, (3) transitoriedad en la regulación excepcional, (4) razonabilidad del medio elegido, es decir, proporción y adecuación entre la medida dispuesta, el fin buscado, y los motivos y causas que han dado origen a la medida de emergencia (Bidart Campos, 2018:203). La doctrina del estado de necesidad exige la concurrencia de determinados requisitos: (a) situación de necesidad; (b) inevitable adopción de una medida apta para enfrentar esa situación de necesidad; (c) un sujeto necesitado (el sujeto que debe tomar la medida o la decisión); y (d) un derecho de necesidad (Sagüés, 2017:498/9).

La emergencia económica, en términos generales, ha tenido en Argentina una profunda y larga trayectoria desde el s. XIX, a lo largo de prácticamente todo el s. XX y lo que va del siglo XXI. Siguiendo a Quiroga Lavié (2009), se pueden identificar los siguientes motivos que llevaron a la declaración de la emergencia en el país en el orden económico-social: Insuficiencia de viviendas (declarada en 1920); escasez de dinero en plaza, distorsión de la oferta y la demanda en el mercado (monopolio de hecho), escasez de trabajo; agio y especulación en los precios, superproducción y, más recientemente, hiperinflación y crisis presupuestaria. Todas estas crisis fueron llevando a la producción de una vasta jurisprudencia de la Corte Suprema de Justicia de la Nación (CSJN), en la gran mayoría de los casos, convalidatoria de las medidas y decisiones tomadas por los poderes públicos (Hernández 2003), en particular, del Ejecutivo, lo que valida jurisprudencialmente la ampliación de sus poderes en los hechos. Este ha sido uno de los puntos en que la doctrina local coincide que en mayor medida ha contribuido al hiperpresidencialismo en nuestro país sin dejar de lado por supuesto también a factores culturales, históricos y otros factores de naturaleza también institucional, como el debilitamiento progresivo del Congreso-.

Actualmente, el país se encuentra bajo emergencia declarada formalmente por el Congreso de la Nación, mediante Ley № 27.541 (publicada en el Boletín Oficial el 23/12/2019), denominada "Ley de solidaridad social y reactivación productiva en el marco de la emergencia pública". Esta ley declara la emergencia pública en materia económica, financiera, fiscal, administrativa, previsional, tarifaria, energética, sanitaria y social, desde su sanción hasta el 31 de diciembre de 2020. En el marco de esta emergencia, la ley hace una serie de delegaciones en el poder ejecutivo. El mismo art. 1o delega en el Poder Ejecutivo nacional una serie de facultades en los términos del artículo 76 de la Constitución Nacional, con arreglo a las bases de delegación establecidas en el artículo $2^{\circ}$, hasta el 31 de diciembre de 2020.

El Art. 2 establece las siguientes bases de delegación:

a) Crear condiciones para asegurar la sostenibilidad de la deuda pública, la que deberá ser compatible con la recuperación de la economía productiva y con la mejora de los indicadores sociales básicos;

b) Reglar la reestructuración tarifaria del sistema energético con criterios de equidad distributiva y sustentabilidad productiva y reordenar el funcionamiento de los entes reguladores del sistema para asegurar una gestión eficiente de los mismos;

c) Promover la reactivación productiva, poniendo el acento en la generación de incentivos focalizados y en la implementación de planes de regularización de deudas tributarias, aduaneras y de los recursos de la seguridad social para las micro, pequeñas y medianas empresas; 
d) Crear condiciones para alcanzar la sostenibilidad fiscal;

e) Fortalecer el carácter redistributivo y solidario de los haberes previsionales considerando los distintos regímenes que lo integran como un sistema único, con la finalidad de mejorar el poder adquisitivo de aquellos que perciben los menores ingresos;

f) Procurar el suministro de medicamentos esenciales para tratamientos ambulatorios a pacientes en condiciones de alta vulnerabilidad social, el acceso a medicamentos e insumos esenciales para la prevención y el tratamiento de enfermedades infecciosas y crónicas no transmisibles; atender al efectivo cumplimiento de la ley 27.491 de control de enfermedades prevenibles por vacunación $\mathrm{y}$ asegurar a los beneficiarios del Instituto Nacional de Servicios Sociales para Jubilados y Pensionados y del Sistema Nacional del Seguro de Salud, el acceso a las prestaciones médicas esenciales;

g) Impulsar la recuperación de los salarios atendiendo a los sectores más vulnerados y generar mecanismos para facilitar la obtención de acuerdos salariales.

Esta ley constituye una de las mayores delegaciones que se han hecho en el Poder Ejecutivo de la Nación. Como puede observarse, la delegación en el presidente de la nación es muy amplia y le encomienda un número importante de objetivos, lo que devela también que el país se encontraba (y se encuentra) atravesando una profunda crisis que alcanza a todos estos factores, entre los que sobresalen el endeudamiento público, la excesiva carga tarifaria sobre los servicios públicos (en especial en materia de energía), cuestiones salariales y previsionales (en materia impositiva), solo por mencionar los más sobresalientes.

Un capítulo importante dentro de todas estas delegaciones está dado por la delegación en materia tributaria. Estas disposiciones han sido fuertemente criticadas como inconstitucionales, además de que carecen de una directiva clara por parte del Congreso para el ejercicio de las facultades delegadas. Incluso, en muchos casos, la delegación en sí parece innecesaria (Spisso 2020).

Por un lado, la inconstitucionalidad de la delegación puede fundarse en las prescripciones precisas del texto constitucional argentino, que en varias de sus disposiciones deja en claro que el único órgano facultado para establecer contribuciones (sean impuestos, tasas o contribuciones) es el Congreso de la Nación (arts. 4을 17 y 52), cuestión que ha sido reafirmada por la inveterada jurisprudencia de la CSJN, dejando en claro que el Congreso es el único poder del Estado investido de tales atribuciones (Fallos 155:290; 248:482; 303:245; 312:912; 316:2329; 318: 1154; $319: 3400 ; 321: 366$ у $263 ; 323: 240$, entre muchos otros - Spisso 2020:43), lo que a su vez invalida a los tributos creados por el Ejecutivo aun cuando con posterioridad fueran convalidados por el Congreso ${ }^{6}$. Si bien el mecanismo de la delegación prevista en el art. 76 de la CN no especifica materias prohibidas de delegación, resulta claro que el Congreso no puede delegar cualquier competencia en el Ejecutivo, entre las que cabe mencionar la materia tributaria. Sobre este punto, la Corte también expidió un fallo en sentido restrictivo ${ }^{7}$. Por otro lado, como sostiene Spisso, la delegación también era innecesaria porque la propia ley establece una serie de reformas importantes a la legislación tributaria: contribuciones patronales, ajuste por inflación, bienes personales, impuesto cedular a la renta financiera, impuesto a las ganancias, impuesto a la compra y cambio de billetes y divisas en moneda extranjera, impuesto sobre débitos $y$ acreditaciones en cuenta bancarias y otra operaciones, tasa de estadística, impuestos internos, exenciones impositivas (2020:46).

6. CSIN, "Luisa Spak de Kupchik y otro c/Banco Central de la República Argentina y otro", de fecha 17/03/1998, Fallos: 321:366, remitiéndose al precedente establecido en "Video Club Dreams" (Fallos: 318:1154 y 319:3400).

7. CSJN, "Camaronera Patagónica S.A. c/ Ministerio de Economía y otros s/ amparo", de 15/04/2014, Fallos: $337: 388$. 
La prohibición de delegar en materia tributaria no sólo comprende la creación de un tributo enteramente nuevo, sino que abarca los elementos esenciales del tributo: hecho imponible, alícuota, sujetos y exenciones - todos ellos alcanzados por el principio de legalidad que impera en esta materia (CSJN, Fallos 329:1554). En este sentido, la delegación al Poder Ejecutivo de incrementar hasta en un $100 \%$ las tasas del impuesto sobre Bienes Personales iría en abierta contradicción con el principio de legalidad.

\section{LA EMERGENCIA PÚBLICA EN ARGENTINA. EL ESTADO DE EMERGENCIA ANTES Y DURANTE LA PANDEMIA.}

Como se vio anteriormente, en marzo de 2020 el país ya se encontraba en situación de emergencia pública, declarada formalmente por Ley del Congreso de la Nación (Ley № 27.541). Desde principios de marzo, el país transitó un momento de crisis inédita, nunca antes vista en su historia - ni en el mundo entero - a raíz de la propagación del Coronavirus, declarado pandemia mundial por la Organización Mundial de la Salud (OMS). El 12 de marzo, el presidente de la república, mediante Decreto № 260, amplió la emergencia pública en materia sanitaria que había establecido la Ley $\mathrm{N}^{\circ} 27.541$, en virtud de la pandemia declarada por la OMS en relación con el coronavirus COVID-19, por el plazo de UN (1) año a partir de la entrada en vigencia del presente decreto. Esta ampliación de una emergencia que, como vimos, sólo el Congreso de la Nación puede establecer, luce también inconstitucional ya que el presidente no puede prolongar una situación sobre la cual no tiene poder de decisión para crearla o declararla en primer lugar, y mucho menos podrá ampliarla o prolongarla. Tampoco el Congreso habilitó esta instancia al Ejecutivo en la Ley 27.551.

El jueves 19 de marzo el presidente emitió el DNU № 297, disponiendo el "aislamiento social preventivo y obligatorio" que rigió desde el 20 hasta el 31 de marzo. La doctrina, e incluso la jurisprudencia, ha sido conteste en reconocer la legitimidad de la medida, tanto en la forma - la utilización de un DNU - como en el fondo - es decir, en cuanto a la razonabilidad de la medida - (ver, entre muchos otros, Hernández 2020a y 2020b; Sabsay 2020), pero su prórroga indefinida ha sido tachada de inconstitucional por gran parte de la doctrina. Frente a la ausencia de un remedio o cura a esta enfermedad, la única solución posible es frenar la marea de contagios a través de lo que el gobierno federal argentino denominó un "aislamiento social obligatorio y preventivo" (tal como lo dispone el art. 1ำ del DNU № 260). En este sentido, se consideró que la medida "constituye una restricción a la libertad ambulatoria $\mathrm{y}$ al derecho de reunión" (Art. 14 de la C.N.). Sin embargo, esta restricción a derechos fundamentales tiene sustento en la exposición de motivos de la norma de la que se extrae, a partir de "las razones de salud pública que dieron origen a la medida adoptada" y que "la medida adoptada -aislamiento social- es la única a disposición que se tiene ante la ausencia de otros recursos médicos que impidan la propagación de la enfermedad"8. La severa restricción que pesa sobre la libertad ambulatoria se ve compensada por el objetivo de preservar el orden público, específicamente la presentación de la salud pública y, dentro de ésta, el derecho a la vida de todos los habitantes del país. El único modo de evitar la propagación del virus es, pues, que todos se queden en sus hogares. Esta medida ha tenido, por supuesto, enormes consecuencias desde todos los puntos de vista: económico, jurídico, social, psicológico y, fundamentalmente, político.

El aislamiento decretado comprende entre el 20 de marzo hasta el 11 de abril del presente año, pero se prorrogó posteriormente varias veces, extendiéndose - hasta la fecha - por más de 180 días consecutivos, aunque ha habido varias flexibilizaciones y etapas ${ }^{9}$.

8. Fallo "Kingston, Patricio s/ Habeas corpus", Interloc. $14 / 143$, Poder Judicial de la Nación, Sala Integrada de habeas corpus - 19.200/2020.

9. La última prórroga se produjo el 20 de septiembre, mediante DNU $\mathrm{N}^{\circ}$ Decreto $754 / 2020$, que representa la undécima prórroga del Aislamiento y del Distanciamiento (según zonas y regiones del país) Social, Preventivo y 
Durante la vigencia de este "aislamiento social", todas las personas "deberán permanecer en sus residencias habituales o en la residencia en que se encuentren a las 00:00 horas del día 20 de marzo de 2020" y "deberán abstenerse de concurrir a sus lugares de trabajo y no podrán desplazarse por rutas, vías y espacios públicos" (art. $2^{\circ}$ ). Frente a la infracción de esta disposición, "se procederá de inmediato a hacer cesar la conducta infractora y se dará actuación a la autoridad competente, en el marco de los artículos 205, 239 y concordantes del Código Penal" (art. 3ํㅜㄹ ${ }^{10}$. Ello salvo algunas excepciones que el propio DNU establece: personal de salud, fuerzas de seguridad, fuerzas armadas, bomberos y control de tráfico aéreo (inc. $1^{\circ}$ ), personal de los servicios de justicia de turno, conforme establezcan las autoridades competentes (inc. $3^{\circ}$ ), solo por mencionar algunos. Estas disposiciones rigieron fundamentalmente en la primera etapa de la cuarentena, ya que con posterioridad los permisos y habilitaciones sobre actividades y personas se flexibilizaron paulatinamente.

Cabe aclarar, asimismo, que la pandemia no está prevista como situación de emergencia en la legislación argentina. El Código Penal Argentino prevé como figura delictiva la violación de "medidas adoptadas por las autoridades competentes, para impedir la introducción o propagación de una epidemia" (art. 205, Cód. Penal Argentino). La pandemia cuadra dentro del supuesto del Estado de sitio, previsto en el art. 23, CN, el cual solo procede en caso de conmoción interior o de ataque exterior y siempre que se ponga en peligro la vigencia de la Constitución y de las autoridades creadas por ella. El efecto de la declaración del estado de sitio implica la suspensión de las garantías constitucionales y, tal como lo

\footnotetext{
Obligatorio.

10. Artículo 205: "Será reprimido con prisión de seis meses a dos años, el que violare las medidas adoptadas por las autoridades competentes, para impedir la introducción o propagación de una epidemia”. Artículo 239: "Será reprimido con prisión de quince días a un año, el que resistiere o desobedeciere a un funcionario público en el ejercicio legítimo de sus funciones o a la persona que le prestare asistencia a requerimiento de aquél o en virtud de una obligación legal".
}

especificaron las autoridades nacionales, la medida lucía demasiado extrema en función de las circunstancias, ya que no había necesidad alguna de suspender las garantías constitucionales. Desde un punto de vista político, la sola mención del instituto rememora épocas de extrema crisis política, institucional y social del país.

Al momento de producirse la emergencia sanitaria, el presidente ya contaba con las herramientas constitucionales para operar en épocas de emergencia. No fue necesario en consecuencia una declaración del Congreso, ya que lo había hecho en diciembre del año anterior. Asimismo, la CN habilita al presidente a utilizar DNU para afrontar situaciones de necesidad y urgencia en cualquier momento, en el sentido de que no necesita ni una declaración previa del Congreso ni una habilitación expresa de éste, porque la facultad emana directamente de la Constitución - pero sí se requiere la aprobación y convalidación posterior del Congreso. Como se verá más adelante, el Congreso, en sus primeras sesiones, convalidó gran parte de las medidas adoptadas por el presidente. A partir de entonces se observa una aplicación progresiva (e innecesaria) de facultades por parte del presidente. En estos primeros momentos, la falta de actuación del Congreso de la Nación, por un lado, y la declaración de feria extraordinaria por parte de la Corte Suprema, por el otro, hizo que en los hechos, funcionara uno solo de los tres poderes del Estado, con la consecuente e inevitable concentración de poderes que ello implicó.

La constitución argentina - como la mayoría de las constituciones latinoamericanas - asigna un rol fundamental al presidente en el proceso de formación y sanción de las leyes, con facultades muy importantes, como el veto (total o parcial), y las facultades de publicación y reglamentación de la ley (que constituye la etapa final del proceso de formación de la ley y sin la cual la ley no llega a adquirir plena vigencia y operatividad, al punto que no puede llegar a ser considerada ley). Dentro de estas facultades, la Constitución le asigna al Ejecutivo una herramienta de 
emergencia que le permite asumir funciones legislativas que en realidad corresponden constitucionalmente al Congreso (Badeni 2006). De acuerdo a la CN, el presidente puede establecer DNU "solamente cuando circunstancias excepcionales hicieran imposible seguir los trámites ordinarios previstos por esta Constitución para la sanción de las leyes". Asimismo, la propia Constitución prohíbe tratar determinadas materias por medio de DNU, a saber: penal, tributaria, electoral o de régimen de los partidos políticos. Para que estos decretos tengan validez, deben, primero, ser decididos en acuerdo general de ministros, y precisan ser refrendados por todos ellos juntamente con el jefe de gabinete de ministros. Asimismo, corresponde al jefe de gabinete de ministros, personalmente, someter la medida a consideración de la Comisión Bicameral Permanente, dentro de los diez días de emitido. La comisión elevará su despacho en un plazo de diez días al plenario de cada Cámara para su expreso tratamiento, el que de inmediato considerarán las Cámaras ${ }^{11}$.

La constitucionalización de estas dos herramientas (DNU y delegación) es una muestra clara del hiperpresidencialismo en Argentina. Ambos institutos generaron amplios debates en la doctrina, entre aquellos en contra de constitucionalizarlos $\mathrm{y}$ aquellos a favor, para quienes la regulación de estos instrumentos ayudaría a limitar y reglamentar su uso. Lo cierto es que desde la presidencia de Menem (1989-1999), el uso de estos instrumentos se volvió en un verdadero abuso, tanto por el número de DNU como por las materias que regulaban (en muchos casos temas muy sensibles tales como la privatización de empresas estatales - y en contextos que ni siquiera justificaban la necesidad ni la urgencia).

Los DNU han sido asiduamente utilizados $\mathrm{y}$, al igual que los decretos delegados, fueron convalidados por la CSJN (Caso "Peralta", 1990). Luego de la reforma constitucional de

11. La Constitución establece que el Congreso deberá dictar una ley especial que regulará el trámite y los alcances de la intervención del Congreso en materia de DNU. Esta ley fue sancionada en julio de 2006, bajo el número Ley 26.122
1994 que expresamente los recepta y regula, la CSJN, en un nuevo fallo (Caso "Rodríguez", 1997), declaró, por un lado, que el control de constitucionalidad de estas medidas no era aplicable, pues se trataba de cuestiones políticas no justiciables y, por el otro, que eran válidos aún en ausencia de ley que reglamente su ejercicio, como dispone el nuevo texto constitucional (Gelli 2004:616). Esta práctica abusiva se instaló durante la presidencia de Carlos Menem. Si bien los DNU existieron en la práctica con anterioridad, tuvieron una aplicación prácticamente insignificante: entre 1853 y 1983 fueron dictados solamente 15 DNU (Molinelli et al 1999:626). El presidente Alfonsín dictó 10 en sus seis años de gestión, Menem dictó cerca de 300 DNU hasta la reforma constitucional de 1994, contabilizando un total de 545 en sus dos períodos presidenciales (19891995 y 1995-1999); De la Rúa (con dos años de gestión, 1999-2001) dictó 73 DNU, el presidente provisorio Duhalde (un año y medio de gestión entre 2002-2003) dictó 158, Kirchner en sus cuatro años y medio de gestión (2003-2007) dictó 270 DNU; la presidente Fernández de Kirchner en sus dos gestiones (2007-2011; 2011-2015) presentó 78 DNU, Macri (en los tres primeros años de los cuatro años de su gestión, 2015-2019), alcanzó a dictar 48 DNU.

El presidente Alberto Fernández (quien asume la primera magistratura el 10 de diciembre de 2019) lleva emitidos alrededor de 50 DNU, la mayoría de los cuales ya han sido convalidados por el Congreso. A pesar de la convalidación, que le da legitimidad definitiva a los decretos, este fenómeno devela un congreso ausente ya que desde la apertura de las sesiones ordinarias el $1^{\circ}$ de marzo hasta mediados de mayo, el Congreso había realizado una sola sesión. Gran parte de estos decretos se dictaron en el marco de la emergencia sanitaria del COVID-1912, pero no todos ellos están estrechamente vinculados con la pandemia, lo que demuestra también un uso abusivo del instrumento por parte

12. “Más de la mitad de los DNU de Alberto Fernández tienen que ver con la pandemia", en https://www. parlamentario.com/2020/04/12/mas-de-la-mitad-delos-dnu-de-alberto-fernandez-tienen-que-ver-con-lapandemia/, 12/04/2020. 
del actual mandatario. Uno de las decisiones más controvertidas ha sido la intervención a la empresa agroindustrial Vicentín (DNU ${ }^{\circ}$ $522 / 2020$, del 9/06/2020), que fue dejada sin efecto poco tiempo después (mediante DNU $\mathrm{N}^{\circ} 636 / 2020$, del $31 / 07 / 2020$ que dispone expresamente la derogación del DNU 522 en su art. $\left.1^{\circ}\right)^{13}$.

A partir de un somero análisis, se puede observar que las principales medidas para combatir la epidemia y contrarrestar sus efectos en los más diversos ámbitos, el presidente dispuso una serie de medidas - aunque temporales - de fuerte impacto, que en realidad debieron ser debatidas y decididas por el Congreso de la Nación ya que se trata de materias que compete decidir a este cuerpo. Entre estas decisiones, se pueden mencionar:

(a) Prohibición de ingreso al territorio nacional de personas extranjeras no residentes en el país por el plazo de 15 días corridos desde 16/3/2020 a $31 / 3 / 2020 \quad$ (DNU N ${ }^{\circ} \quad 274 / 2020$ del 16/03/2020). Plazo prorrogado sucesivamente con posterioridad, y ampliado su alcance a las personas residentes en el país y aquellos con residencia en el exterior (DNU $\mathrm{N}^{\circ}$ $313 / 2020$, del 27/03/2020).

(b) Obligación de retrotraer los precios al 06/03/2020 de productos que conforman la canasta básica de alimentos, bebidas, higiene personal y limpieza (Resolución $\mathrm{N}^{\circ} 100$ de la subSecretaría de Comercio Interior (SCI), del 20/03/2020);

(c) Creación del Ingreso Familiar de Emergencia (IFE), destinado personas que se encuentren desempleadas; se desempeñen en la economía informal

13. Ver "Vicentin: Alberto dejó sin efecto el DNU de intervención y expropiación", Ámbito, 31 Julio 2020, https://www.ambito.com/politica/alberto-fernandez/ vicentin-alberto-dejo-efecto-el-dnu-intervenciony-expropiacion-n5121544; "El Gobierno derogó el decreto que disponía la intervención de Vicentin", Telam, 31/07/2020, https://www.telam.com.ar/ notas / 202007/496881-alberto-fernandez-gobiernonacional-vicentin.html. o cuyos ingresos no lleguen al salario mínimo vital y móvil, entre otros, con el objetivo de "compensar la pérdida o grave disminución de ingresos de personas afectadas por la situación de emergencia sanitaria declarada por el Decreto $\mathrm{N}^{\circ}$ 260/20" (art. $1^{\circ}$ ) (DNU 310/2020, del 23/03/2020);

(d) Prohibición a las empresas prestadoras de los servicios básicos (energía eléctrica, gas, agua corriente, telefonía fija o móvil, Internet, TV por cable, por vínculo radioeléctrico o satelital) a suspender los servicios, por causa de mora o falta de pago de hasta tres facturas consecutivas o alternas, con vencimientos desde el 1/3/2020 (DNU $\mathrm{N}^{\circ} 311 / 2020$, del 24/03/2020);

(e) Suspensión de desalojos en inmuebles destinados a vivienda única, prórroga de la vigencia de contratos locativos y congelamiento del precio de los alquileres hasta el 30 de septiembre de 2020 (DNU N $^{\circ} 320 / 2020$ del 29/03/2020);

(f) Congelamiento de cuota mensual de los créditos hipotecarios sobre inmuebles con destino a vivienda única y suspensión de las ejecuciones hipotecarias, judiciales o extrajudiciales hasta el 30/9/2020 (DNU N 319/2020, del 29/03/2020);

(g) Prohibición de despidos sin justa causa y por las causales de falta o disminución de trabajo y de suspensiones y despidos por fuerza mayor por 60 días contados a partir del 31/3/2020 (DNU $\mathrm{N}^{\circ} 329 / 2020$ del 31/03/2020);

(h) Inclusión de COVID-19 como una enfermedad de carácter profesional a cubrir por las ART (DNU N ${ }^{\circ} 367 / 2020$, del 13/04/2020).

(i) Congelamiento y suspensión de cortes de servicios de telefonía móvil e internet hasta el 31 de mayo de 2020 (DNU N ${ }^{\circ} 311$ del 24/04/2020; DNU ${ }^{\circ}$ 426, del 30/04/2020); 
Más allá de la bondad de estas medidas - que no se discute - lo cierto es que representan decisiones tomadas de manera unilateral por el presidente, y reflejan sin dudas el predominio de la figura presidencial en el sistema político argentino, sobrepasando o invadiendo competencias propias del poder legislativo.

En este sentido, una medida que refleja la excesiva concentración de poder en el presidente ha sido, sin lugar a dudas, la ampliación (del ya de por sí vasto) poder del presidente de reasignar partidas presupuestarias, dispuesta por DNU. Esta facultad (denominada vulgarmente como "superpoderes") había sido otorgada (o mejor dicho, delegada) por el Congreso mediante Ley № 24.156 de Administración Financiera y de los Sistemas de Control del Sector Público Nacional (Art. 37), la que señala que el jefe de Gabinete de Ministros puede disponer las reestructuraciones presupuestarias que considere necesarias dentro del monto total aprobado, las que no podrán superar el 5\% (a partir del ejercicio 2018 y siguientes) del monto total aprobado por cada ley de presupuesto, ni el 15\% del presupuesto aprobado por finalidad, cuando se trate de incrementos de gastos corrientes en detrimento de gastos de capital o de aplicaciones financieras, y/o modificaciones en la distribución de las finalidades.

El DNU $N^{\circ} 457 / 20(10 / 05 / 2020)$, en cambio, ordena directamente la suspensión "durante el ejercicio 2020, para aquellas modificaciones presupuestarias necesarias en virtud de medidas dictadas en el marco de las disposiciones del Decreto $\mathrm{N}^{\circ}$ 260/20, [de] la aplicación de los límites a las reestructuraciones presupuestarias que puede disponer el Jefe de Gabinete de Ministros, establecidos en el tercer párrafo del artículo 37 de la Ley № 24.156 de Administración Financiera y de los Sistemas de Control del Sector Público Nacional". Lo anterior significa que el Jefe de Gabinete no tiene límite alguno para reasignar partidas presupuestarias. Además, mediante este mismo DNU 457, el presidente dispuso diversas reasignaciones de partidas a favor de organismos federales (tales como ANSeS,
Ministerio de Salud, de Desarrollo Productivo y Desarrollo Social e Interior), elevando el déficit fiscal en $\$ 76.456$ millones.

La medida generó preocupación y cierta reacción por parte de la oposición. Gran parte de los bloques opositores, en particular, bloques de Juntos por el Cambio, el Interbloque Federal, como también de los bloques Consenso Federal, Socialista y Justicialista expresaron desacuerdo y rechazo al DNU. La fuerza opositora Juntos por el Cambio presentó un proyecto para rechazar el DNU 457/20, por considerar que la decisión "cercena las facultades del Congreso"14. A pesar de estos pedidos de derogación del decreto (en particular, su polémico art. $4^{\circ}$ ), tanto en la Cámara de Diputados como en la del Senado, la comisión Bicameral Permanente de Trámite Legislativo prevista por el Art. 99 inc. 3, CN (encargada de analizar la validez de estas medidas), dio su aprobación mediante dictamen favorable, aunque avalado sólo por la mayoría oficialista del bloque Frente de Todos.

\section{EL CONGRESO DE LA NACIÓN Y SU FUNCIONAMIENTO DURANTE LA EMERGENCIA}

El rol del parlamento durante la pandemia merece una consideración especial. No cabe duda de que los parlamentos son la institución más importante dentro de las repúblicas modernas. El Congreso es, como ha dicho nuestra CSJN, el "órgano más íntimo del país -según las palabras de Alberdi-"15, y su normal funcionamiento es esencial para el sostenimiento del orden democrático, republicano y constitucional. Ello es especialmente cierto en épocas de crisis como la que se está atravesando.

14. Ver "La oposición se reagrupa para rechazar el DNU que otorga 'superpoderes' a Santiago Cafiero", infobae, miércoles 13 de Mayo de 2020, https://www.infobae. com/politica/2020/05/13/la-oposicion-se-reagrupapara-rechazar-el-dnu-que-otorga-superpoderes-asantiago-cafiero/.

15. CSJN, "Unola de Argentina Ltda. c/ Y.P.F. y BANADE s/ contrato de obra pública", del 6 de octubre de 1998, Fallos 321:2683. 
El DNU N² 297 incluía al poder legislativo entre las excepciones al ASPO y este poder, en los tres niveles de gobierno, debe continuar operativo. El inc. $2^{\underline{o}}$ del art. $4^{\mathrm{o}}$ dispone expresamente que quedan exceptuadas las "autoridades superiores de los gobiernos nacional, provinciales, municipales y de la Ciudad Autónoma de Buenos Aires, Trabajadores y trabajadoras del sector público nacional, provincial, municipal y de la Ciudad Autónoma de Buenos Aires, convocados para garantizar actividades esenciales requeridas por las respectivas autoridades". Una decisión que impida el funcionamiento de los demás poderes en los distintos niveles de gobierno hubiera significado, sin más, un auto-golpe de Estado.

El interrogante que surgió fue por el modo en que debían o podían continuar su labor parlamentaria, sin poner en riesgo la salud de los legisladores, de los trabajadores y de la población en general, ya que se trata de órganos colegiados que necesariamente requieren de la concentración de personas para operar y funcionar. Ello por cuanto la normativa interna sobre funcionamiento de estos órganos legislativos no prevé modalidades de operación en épocas de crisis como la que se está viviendo - lo que resulta paradójico atento a los avances tecnológicos que ha habido en las últimas décadas en materia de comunicación -. En este sentido, se observa un amplio abanico de respuestas y estrategias adoptadas tanto en nuestro país (en sus tres niveles de gobierno: federal, provincial y municipal) como en todos los demás países afectados por el COVID-19, que han decretado medidas de "aislamiento social obligatorio" como medida de prevención para evitar la propagación del virus (Altavilla 2020).

Al momento de emitirse el DNU 297 por el cual se estableció el ASPO a partir del 20 de marzo, el Congreso de la Nación se encontraba ya en funcionamiento. De acuerdo a la $\mathrm{CN}$, las sesiones ordinarias se inician el 1 de marzo de cada año (art. 63, $\mathrm{CN}^{16}$ ). A pesar de ello, el Congreso no

16. Artículo 63.- Ambas Cámaras se reunirán por sí mismas en sesiones ordinarias todos los años desde el comenzó a funcionar sino casi dos meses después de establecida la cuarentena, luego de varios debates y conflictos en torno a la posibilidad de sesionar online. De hecho, la cuestión del funcionamiento del Congreso comenzó a debatirse cuando surgió la propuesta de establecer un impuesto a las grandes fortunas, no antes con respecto por ejemplo, al control de los DNU emitidos por el presidente ${ }^{17}$.

La cuestión se planteó por el hecho de que ni el reglamento de la Cámara de Diputados ni el de la Cámara de Senadores preveían la posibilidad de sesionar de manera remota u online. Así, por ejemplo, el artículo 30 del Reglamento de la Cámara de Senadores de la Nación dispone que los senadores constituyen Cámara en la Sala de Sesiones, salvo casos de "gravedad institucional", pero no establece mecanismos precisos sobre cómo desarrollar las sesiones en esos casos de excepcionalidad. Si bien es cierto que al momento de decretarse el aislamiento, la mayoría de los legisladores se encontraban en sus hogares y que muchos de ellos son personas en riesgo por su edad, lo que dificultó la reanudación y reactivación de la actuación parlamentaria (sobre todo en un país de extensas dimensiones como lo es Argentina), también se perdió un valioso tiempo, sobre todo al inicio de la emergencia, en discusiones sobre cuestiones técnicas referidas a la posibilidad de sesionar de manera remota y de otras alternativas posibles, cuando en otros países (como Ecuador o Brasil) la respuesta de los parlamentos fue mucho más rápida y eficiente.

Tanto el Senado como la Cámara de Diputados reanudaron las labores parlamentarias el 13 de mayo, de manera virtual. El Senado, luego de la decisión de la CSJN y de arduos debates entre los bloques,

\footnotetext{
primero de marzo hasta el treinta de noviembre. Pueden también ser convocadas extraordinariamente por el presidente de la Nación o prorrogadas sus sesiones.

17. A los pocos días de establecerse el ASPO, la Presidenta del Senado dispuso la interrupción de los plazos parlamentarios (Decreto $\mathrm{N}^{\circ} 4 / 20$ del 25/03/2020), lo que en los hechos "significó que no está funcionando el Senado" (Hernández 2020).
} 
decidió realizar sus sesiones de manera remota a partir de un acuerdo entre los bloques políticos que conforman la Cámara. En este acuerdo se aceptó realizar sesiones remotas, pero sujeto a la condición de que tales sesiones se atendieran cuestiones relacionadas con el Derecho de emergencia decretada en el marco de la pandemia del COVID-19. Este compromiso fue plasmado en un decreto presidencial parlamentario, emitido por la presidente del Senado, en virtud del cual se convocaba a sesión remota, estableciendo las bases de funcionamiento ad referéndum del pleno. El Decreto de la Presidencia del H. Senado de la Nación $\mathrm{N}^{\circ}$ 8/2020 del 4 de mayo de 2020, en su art. $1^{\circ}$ dispone: "encomiéndese la realización de sesiones en carácter remoto o virtual mediante videoconferencia, de modo excepcional por el plazo de SESENTA (60) días, plazo que podrá ser prorrogado por el H. Senado de la Nación en tanto persista la situación de emergencia sanitaria que diera lugar al dictado del presente decreto". Más importante aún, en su art. $2^{\circ}$ se delimita el ámbito de actuación del Senado en este contexto de emergencia y en este modo particular de actuación remota (excepcional y por tiempo determinado) mediado por tecnologías: "las sesiones virtuales o remotas tratarán sobre medidas específicas en el marco de la emergencia sanitaria declarada a raíz del COVID-19, sobre aquellas leyes que requiera el Poder Ejecutivo Nacional y aquellas iniciativas que a criterio del $\mathrm{H}$. Congreso de la Nación sean necesarias para combatir el COVID-19, sus consecuencias y las que deriven de las medidas para prevenir la pandemia o sus efectos".

En los propios fundamentos del Decreto se menciona que "el interbloque de Juntos por el Cambio [principal fuerza opositora] manifestó que consideran 'imprescindible alcanzar un acuerdo político que viabilice el funcionamiento del Senado en el referido contexto de pandemia'". El decreto recopila los argumentos y manifestaciones de todos los demás bloques parlamentarios que componen la Cámara. La modalidad escogida y utilizada por el Senado fue la de sesiones completamente remotas - a diferencia de la Cámara de Diputados, que optó por un modelo de sesiones mixto - mientras durara la pandemia y por el plazo de 60 días, prorrogado por otro plazo similar de 60 días en el mes de junio, y hasta agosto ${ }^{18}$. En oportunidad de prorrogar las sesiones remotas, un grupo de senadores había solicitado la adopción de una modalidad mixta, con la posibilidad de presencia física en el recinto de algunos senadores. El pedido fue desestimado, bajo el argumento de que "admitir el sistema mixto implicaría una inaceptable e infundada desigualdad de tratamiento entre los senadores que residen y se encuentran en provincias lejanas a la Capital Federal y quienes residen en la propia Capital o en provincias cercanas". En cambio, la Cámara de Diputados dispuso una modalidad semi-remota o mixta ${ }^{19}$ con la presencia física de un número determinado de diputados en el recinto, y los restantes diputados de manera remota. El día 13 de mayo, la Cámara realizó su primera sesión, con la presencia de 47 legisladores en sus bancas, mientras que 210 diputados integraron el recinto virtual. En esa primera sesión, el plenario de la Cámara aprobó (con un resultado de 248 votos afirmativos contra 2 negativos) el Protocolo de Funcionamiento Parlamentario Remoto por el que se establecen las pautas para el desarrollo de las sesiones remotas ${ }^{20}$.

En sus primeras sesiones, ambas cámaras se abocaron al análisis y eventual aprobación de los DNU que había dictado hasta entonces el Poder Ejecutivo Nacional. En su primera sesión remota, el Senado aprobó 20 DNU firmados por el presidente Fernández, todos ellos relacionados con la pandemia del coronavirus. 18 de ellos fueron aprobados por unanimidad, mientras que dos DNU fueron rechazados por parte de la oposición (Juntos por el Cambio): el DNU $\mathrm{N}^{\circ} 313$, que ordenaba el cierre de las fronteras del país

18. Decreto de la Presidencia del H. Senado de la Nación N" 11/20, de fecha 21 de Julio de 2020.

19. Ver "Diputados realiza la primera sesión virtual de su historia" Télam, https://www.telam.com.ar/ notas/202005/463086-en-el-senado-y-en-diputadosse-realizaran-las-primeras-sesiones-virtuales-de-suhistoria.html.

20. Ver "medidas de la HCDN ante el COVID-19", https:// www.hcdn.gob.ar/institucional/infGestion/covid19/ index.html. 
y el DNU $\mathrm{N}^{\circ} 329$, por el que se prohíben los despidos sin justa causa, o por causales de falta o disminución de trabajo y por fuerza mayor $^{21}$.

La actividad parlamentaria ha sido bastante intensa desde entonces en ambas cámaras. Desde la renovación parcial de 2019, el bloque oficialista Frente de Todos tiene 119 diputados en la Cámara de Diputados (que tiene un total de 257 miembros), mientras que la principal fuerza opositora, Juntos por el Cambio, tiene 116 bancas. El quórum - previsto en el art. $64 \mathrm{CN}$ al establecer que "Ninguna de [las Cámaras] entrarán en sesión sin la mayoría absoluta de sus miembros" - se logra con 129 legisladores, por lo que el oficialismo necesita la participación de los demás sectores políticos para lograrlo e iniciar las sesiones. En el Senado, en cambio, el Oficialismo cuenta con 41 bancas, de las 72 totales que tiene la Cámara Alta ${ }^{22}$, es decir, el $57 \%$ de la Cámara, mientras que Juntos por el Cambio tiene 25 bancas (el 35\%) y otros sectores, también de la oposición, ocupan las restantes bancas ${ }^{23}$.

Desde la reanudación de la actividad parlamentaria, ha habido más sesiones que en todo el año 2019 y la mayoría leyes fueron sancionadas por unanimidad ${ }^{24}$. De acuerdo

21. “En sesión remota, el Senado aprobó los 20 decretos del Poder Ejecutivo", Página 12, jueves 14 de mayo de 2020, disponible en: https://www.pagina12.com. ar/265809-en-sesion-remota-el-senado-aprobo-los-20decretos-del-poder-.

22. Desde la reforma de 1994, el Senado se compone de 3 senadores por provincia y 3 por la Ciudad Autónoma de Buenos Aires. En el texto constitucional de 1853 las provincias contaban con dos senadores, igual que en la federación norteamericana. Así lo establece el Art. 54, $\mathrm{CN}$ : "El Senado se compondrá de tres senadores por cada provincia y tres por la ciudad de Buenos Aires, elegidos en forma directa y conjunta, correspondiendo dos bancas al partido político que obtenga el mayor número de votos, y la restante al partido político que le siga en número de votos".

23. Bloque Parlamentario Federal, 4 bancas (6\%) y dos bloques unipersonales (con una sola banca), Bloque Misiones y Juntos Somos Río Negro.

24. Ver "Los 150 días del Congreso: leyes por unanimidad, asistencia perfecta y un diálogo difícil de mantener", Infobae, disponible en: https://www.infobae. com/politica/2020/08/16/los-150-dias-del-congresoleyes-por-unanimidad-asistencia-perfecta-y-un-dialogodificil-de-mantener/. al SAIJ (Sistema Argentino de Información Jurídica), el Congreso lleva sancionadas 16 leyes, de las cuales 6 no tienen ninguna vinculación con la emergencia sanitaria, y otras dos se refieren a cuestiones económico-presupuestarias.

Algunos proyectos suscitaron fuertes conflictos y reclamos por parte de los sectores opositores. Se trata de proyectos que no están vinculados estrictamente a la cuestión de la emergencia sanitaria. Entre ellos, por ejemplo, la sanción de la Ley $\mathrm{N}^{\circ}$ 27.55, sancionada en sesión especial el 11 de junio de 2020, por la que se introduce una serie de modificaciones al régimen de locaciones habitacionales que prevé el Código Civil y Comercial de la Nación (CCyC). Este proyecto en particular ya había sido aprobado por la Cámara de Diputados, por unanimidad, a fines de 2019 y contaba con el apoyo de todos los sectores del Senado, pero su introducción de último momento en el orden del día causó sorpresa y malestar en los sectores opositores. Además, en el caso puntual del Senado, generó ciertos debates que giraban en torno a la constitucionalidad misma de la ley, ya que el Decreto parlamentario que autoriza las sesiones virtuales, lo hace sobre "medidas específicas en el marco de la emergencia sanitaria declarada a raíz del COVID-19" (art. $2^{\circ}$, Decreto de la Presidencia del H. Senado de la Nación $\left.N^{\circ} 8 / 2020\right)^{25}$.

Otro proyecto controvertido ha sido el presentado por el presidente de la nación sobre reforma judicial (que ya cuenta con media sanción en el Senado). El tratamiento de estos temas que no están estrictamente vinculados con la pandemia y la emergencia sanitaria conlleva a una serie de conflictos y reclamos por parte de diferentes sectores políticos y sociales, dejando en duda también la constitucionalidad de tales medidas. Estas cuestiones traen a colación consideraciones acerca de cuál debería ser el objeto de las sesiones y sobre qué es lo que debería hacer el parlamento en época de pandemia,

25. Sobre el análisis acerca del control de constitucionalidad formal, es decir, sobre los aspectos formales del proceso de sanción de normas y leyes, puede verse Altavilla y Sola 2020. 
cuestión que en última instancia se vincula también con el principio constitucional de razonabilidad: ¿ es razonable que el Congreso sesione en épocas de emergencia para situaciones normales que regirán a futuro? Lo cierto es que estos proyectos generaron peleas internas en las Cámaras que distraen el debate de los asuntos más importantes y urgentes que plantea la pandemia y la emergencia económica y social que atraviesa el país, y ponen de relieve actitudes reñidas con el consenso y el acuerdo entre los sectores políticos.

\section{EL ROL DEL PODER JUDICIAL EN LA CRISIS}

El Poder Judicial en Argentina está compuesto por el poder judicial federal y los respectivos poderes judiciales provinciales. La federación argentina se caracteriza por una fuerte centralización de competencias legislativas en manos del Congreso de la Nación, ya que la Constitución delega en este órgano federal la sanción de los códigos de fondo (civil, comercial, penal, laboral, etc.), pero en lo que hace a su aplicación, en gran medida, son aplicados y juzgados por los tribunales provinciales, por lo que se puede afirmar que el federalismo judicial en Argentina es bastante descentralizado (Barrera Buteler 2017).

En lo que respecta al poder judicial federal, está compuesto por "una Corte Suprema de Justicia, y por los demás tribunales inferiores que el Congreso estableciera en el territorio de la Nación" (art. 108, CN). La Corte Suprema es la cabeza del poder judicial federal. Desde el inicio de la pandemia y del establecimiento del ASPO por parte del Ejecutivo Nacional, los poderes judiciales (federal y provinciales) dispusieron una feria judicial extraordinaria, un cese de las actividades, con la reserva de una guardia mínima para atender cuestiones urgentes (por ejemplo, amparos y habeas corpus). A nivel federal, la CSJN emitió la Acordada $\mathrm{N}^{\circ}$ 04/2020 (del 16/03/2020) por la que se declaró inhábiles los días 16 al 31 de marzo, y luego por Acordada $\mathrm{N}^{\circ}$ 06/20 (emitida con posterioridad al DNU $\mathrm{N}^{\circ} 297$ que instaura el ASPO), por la que se dispone una feria extraordinaria hasta el 31 de marzo, manteniendo la atención de las cuestiones penales y de familia o salud. Fue sucesivamente extendida por Acordadas $\mathrm{N}^{\circ}$ 8,10 y 13 .

Por Acordada $\mathrm{N}^{\circ}$ 14/20 (11 de mayo de 2020) se volvió a prorrogar la feria, pero en esta misma normativa se estableció una serie de protocolos para el nuevo funcionamiento del poder judicial y se profundizó en la utilización de tecnologías como las resoluciones digitales y la firma electrónica. Asimismo, se dispuso durante esta feria extraordinaria que la Corte Suprema de Justicia de la Nación funcionara con todos sus miembros y secretarios de Corte. Luego, por Acordada $N^{\circ} 17 / 20$ (del 02/06/2020) se facultaba el levantamiento de esta feria extraordinaria en aquellas jurisdicciones federales que lo solicitaron, con excepción de los tribunales de la Capital Federal, y por Acordada $\mathrm{N}^{\circ} 27 / 20$ del 20/07/2020 se dispuso el fin de la feria desde el 27 de julio, con reinicio de los plazos procesales a partir del 4 de agosto.

En este contexto, la actuación del Poder Judicial, tanto a nivel federal como a nivel provincial, se mantuvo al mínimo y para casos de urgencia. Aunque es necesario considerar que la situación en las distintas provincias es variable, principalmente por las distintos grados de utilización de medios tecnológicos en los procesos judiciales. Lo anterior hizo que en algunas jurisdicciones se continuara con la labor judicial, mientras que en otras la adaptación al contexto de distanciamiento fue más lenta.

La mayoría de los pronunciamientos judiciales emitidos durante la pandemia se refirieron a las restricciones de derechos fundamentales, en particular, a través de Amparos y Habeas Corpus. Uno de los primeros pronunciamientos fue el caso "Kingston, Patricio s/ Habeas corpus" (citado anteriormente) donde se declaró la razonabilidad y legalidad de la medida impuesta por el DNU N ${ }^{\circ} 297^{26}$. En lo sucesivo,

26. Ver también Cámara Nacional Criminal y Correccional de Buenos Aires, "Blanco Peña, M. L. s/ habeas corpus", Sala V, sentencia del 29/05/2020. 
la mayoría de los pronunciamientos judiciales se refirieron al exceso en la aplicación de las limitaciones, en particular de la circulación de una provincia a otra, o el egreso o ingreso a una localidad cuestiones que también generaron serios conflictos intergubernamentales - como también de ingreso al país de personas que se encontraban varadas en el exterior. Con respecto a las restricciones impuestas por las propias provincias en cuanto a la circulación o a las medidas preventivas (por ejemplo, de realizar cuarentena al ingresar a una provincia), hubo fallos diversos, que, sobre el mismo hecho, resolvieron de manera completamente distinta ${ }^{27}$. Otra cuestión muy sensible que motivó la presentación de habeas corpus fue la precaria situación de las personas privadas de la libertad ${ }^{28}$.

Con respecto a la Corte Suprema de Justicia de la Nación, hubo pocos pronunciamientos de relevancia en el marco de la pandemia. En términos generales, se puede sostener que si bien no ha habido pronunciamientos relacionados a las restricciones de derechos fundamentales por las medidas de confinamiento, se puede argumentar que la Corte ha avalado la validez de los DNU de manera indirecta. Uno de ellos ha sido frente al reclamo de particulares que exigían el ingreso a determinadas provincias y localidades, impedida por las fuerzas de seguridad locales ${ }^{29}$. La Corte, en estos casos, dispuso requerir informes a las provincias involucradas (Provincia de Corrientes y San Luis) para que dieran cuenta sobre las medidas y protocolos adoptados por las autoridades provinciales en el marco del aislamiento social, preventivo y obligatorio (ASPO) previsto por el DNU $\mathrm{N}^{\circ} 297 / 20$ que

27. Por ejemplo, frente al amparo interpuesto por productores agropecuarios de la provincia de Córdoba contra la vecina provincia de San Luis frente al impedimento de acceso a la provincia, hubieron dos pronunciamientos federales, uno a favor y otro en contra de lo solicitado.

28. Ver al respecto, Robles 2020 y Benente y Ferrando Kozicki 2020.

29. CSJN, CSJN, "Sociedad Rural de Río Cuarto y otros c/ Provincia de San Luis - Poder Ejecutivo s/ amparo ley 16.986", del 10 de septiembre de 2020; "Maggi, Mariano c/ Corrientes, Provincia de s/ medida autosatisfactiva", del 10 de septiembre de 2020. rigen en la actualidad, y de las razones que podrían justificar que se le impida el ingreso al territorio de la provincia a las ciudadanos accionantes, librándose oficio por medios electrónicos al señor Gobernador provincial. Asimismo, la Corte hizo lugar a las medidas cautelares solicitadas, inter se tramitan las causas.

El fallo más relevante dictado por la CSJN se refirió a la posibilidad del Senado de sesionar de manera online. Si bien la Corte en este caso no decidió nada, pues consideró que se trataba de una competencia propia de otro poder por lo que, en función del principio de división de poderes propio del sistema republicano no le correspondía resolver, resulta interesante porque trae a colación la consideración de varios aspectos que hacen al sistema político y constitucional argentino, tales como el de control de constitucionalidad, la doctrina local sobre cuestiones políticas no judiciables, división de poderes, etc. La resolución se origina a raíz de una acción declarativa de certeza interpuesta el 16 de abril por la Presidenta de la Cámara de Senadores, Cristina Fernández de Kirchner (ex presidente de la nación, 2007-2011 y 2011-2015), por la cual se "consultaba" a la Corte sobre la posibilidad de sesionar online por parte del Senado. En particular, la acción iba dirigida a obtener una respuesta por parte del máximo tribunal de la siguiente pregunta: " $i$ es constitucionalmente posible que, tal como lo dispone el Art. 30 del Reglamento del Senado, sesione mediante medios virtuales debido a la situación de gravedad institucional generada objetivamente por el COVID19?". La Corte, luego de una extensísima consideración sobre el caso - con un interesante análisis de derecho comparado (véase Carnota $2020^{30}$ ) - concluyó, en mayoría, que "se resuelve que el Senado de la Nación tiene todas las atribuciones constitucionales para interpretar su propio reglamento en

$30 . \quad$ "Todas las opiniones -mayoría, concurrencia y
minoría- se van a detener en el perfil del "caso", con más
o menos profusión de argumentos. El voto que abre el
acuerdo de la Corte -y que constituirá mayoría- trae a
colación sin embargo interesantes aportes del derecho
constitucional comparado, más allá del "caso", y permiten
explicar cómo en definitiva resolvió" (Carnota 2020). 
cuanto a la manera virtual o remota de sesionar, sin recurrir a la Corte Suprema de Justicia de la Nación, por lo cual se rechaza la acción incoada" ${ }^{31}$ (firmado por los jueces Nolasco, Maqueda, Lorenzetti, Rosatti - voto concurrente - y Rosenkrantz - en disidencia parcial). En su disidencia parcial, el ministro Carlos Rosenkrantz directamente resolvió rechazar in limine la presentación.

La resolución se basó en varios fundamentos, de los cuales cabe rescatar dos, que definen el control jurisdiccional en el sistema argentino:

(a) la doctrina de las cuestiones políticas no judiciables: "en el caso «Barrick», fallado en el año 2019, este Tribunal recordó que desde tiempos muy tempranos su jurisprudencia «ha reconocido límites a las cuestiones justiciables, $\mathrm{y}$ ha sido muy prudente al momento de controlar el procedimiento o trámite parlamentario de las leyes formales»; con cita en el célebre caso «Cullen c/ Llerena», del año 1893, que añadió que «el departamento judicial no podía contestar ni sobre el fondo ni sobre la forma de las deliberaciones en las que el Congreso había ejercido una atribución política»" y que "constituía «una regla elemental de nuestro derecho público, que cada uno de los tres altos poderes que forman el Gobierno de la Nación, Aplica e interpreta la Constitución por sí mismo, cuando ejercita las facultades que ella les confiere» (Fallos: 53:420)" (voto concurrente del Ministro Rosatti).

(b) Asimismo, a diferencia de los tribunales o cortes constitucionales de otros países, la Corte argentina no resuelve sobre cuestiones abstractas: "esta Corte sostuvo recientemente en «Barrick», sentencia del 4 de junio de 2019 (Fallos: 342:917) que constituye «inveterada doctrina» de su jurisprudencia «que sus pronunciamientos se encuentran condicionados a la presentación de 'casos justiciables' («Constantino Lorenzo», Fallos: 307:2384, entre muchos otros)»" y que esta condición "se configura

31. CSJN, "Fernández de Kirchner, Cristina en carácter de Presidenta del Honorable Senado de la Nación s/ acción declarativa de certeza", sentencia del 24 de abril de 2020 . cuando concurren dos recaudos: por una parte, debe tratarse de una controversia que persigue la determinación del derecho debatido entre partes- adversas, fundado en un interés específico, directo, o inmediato atribuible al litigante; por otra, la causa no debe ser abstracta en el sentido de tratarse de un planteo prematuro o que hubiera devenido insustancial". Estos mismos recaudos son aplicables también a las acciones declarativas, "dado que este procedimiento no tiene carácter simplemente consultivo, ni importa una indagación meramente especulativa" ${ }^{32}$.

\section{CONCLUSIONES}

La república Argentina vive en una situación de "emergencia permanente". Prácticamente desde 1920, rigen en el país leyes de emergencia, en la mayoría de los casos económica. Lo anterior, naturalmente, ha llevado a una excesiva concentración de poderes en manos del poder ejecutivo nacional. Una emergencia tan grave $\mathrm{y}$ profunda, con consecuencias todavía no mensurables, como la que ha provocado la pandemia del COVID-19, justificó la utilización de todas estas herramientas de emergencia. Por ello, en los primeros meses de la pandemia, las medidas tomadas por el presidente recibieron el beneplácito de todo el arco político, de la doctrina y de la gran mayoría de la población. Además, estas primeras medidas fueron tomadas de manera consensuada con los principales actores políticos del sistema, quienes podían ser vistos junto al presidente a la hora de anunciar las medidas (jefes de bloques parlamentarios y gobernadores). Estas decisiones fueron tomadas luego de largas reuniones mantenidas con los diferentes representantes políticos.

Sin embargo, con el transcurrir del tiempo, muchas medidas - sobre todo aquellas que no estaban vinculadas estrechamente con la pandemia - comenzaron a generar reclamos y malestar en muchos sectores de la sociedad (principalmente, el político). No pasó mucho tiempo para que la pandemia pusiera de resalto el viejo problema del

32. Ídem. 
presidencialismo y la excesiva concentración de facultades en este órgano. En este sentido, la pandemia no hizo otra cosa que poner de resalto las antiguas molestias que aquejan al país y, en muchos casos, lo ha empeorado, como puede observarse con el agravamiento de la situación económica y el aumento de los niveles de pobreza, que se estima aumentaría del 35,6\% al 40,2\%, la indigencia del 7,7\% al $10,8 \%$, y la desigualdad del $23 \%$ al $32,5 \%{ }^{33}$.

33. ONU, "La pobreza en Argentina aumentará del 35,6\% al 40,2\% debido al coronavirus", (https://news.un.org/ es/story/2020/06/1476542), basado en el informe de ONU "Análisis inicial de las Naciones Unidas. COVID-19
$\mathrm{Si}$ bien las situaciones de emergencia tienden naturalmente a la concentración de poder, por un lado, este fenómeno no puede prolongarse indefinidamente, y por el otro, es fundamental para el buen funcionamiento de la república y del sistema democrático el pleno funcionamiento de todos los poderes del Estado, en particular del Congreso, que tiene la tarea de representar al pueblo y de controlar las medidas y decisiones del Ejecutivo.

en Argentina: impacto socioeconómico y ambiental. Actualizado al 19/06/2020", disponible en: http://www. onu.org.ar/stuff/Informe-COVID-19-Argentina.pdf.

\section{REFERENCIAS BIBLIOGRÁFICAS}

» Alberdi, Juan B. [1852] (1994). Bases y Puntos de Partida para la Organización Política de la República Argentina. Buenos Aires: Plus Ultra.

» Altavilla, Cristian. (2016). Conflicto y Coordinación política en las Relaciones Intergubernamentales en Argentina. Un análisis neoinstitucional a través del Régimen de Coparticipación Federal de Impuestos. Tesis Doctoral. Córdoba: Universidad Nacional de Córdoba.

» Altavilla, Cristian. (2020). "La actividad legislativa en tiempos de crisis ¿Pueden sesionar virtualmente los parlamentos?", en Altavilla, Cristian y Villegas, Candela (Dirs.), Los desafíos del Derecho frente a la Pandemia COVID-19. Mirada del Derecho Argentino con aportes del Derecho Comparado (pp. 23-30). Buenos Aires: IJ Editores / Universidad Siglo 21.

» Altavilla, Cristian y Sola, Victorino. (2020). "A propósito de dos tesis (sustancial y formal) en torno del test de constitucionalidad de la Ley $\mathrm{N}^{\circ}$ 27.551", en Altavilla, Cristian, Miguel, Federico y Nini Zalazar, Sebastián (Dirs.), Implicancias Jurídicas del Nuevo Régimen Locativo Argentino. Buenos Aires: IJ Editores / Universidad Siglo 21.

» Badeni, Gregorio. (2006). Tratado de Derecho Constitucional. Tomo II (2ª ed.). Buenos Aires: La Ley.

» Barrera Buteler, Guillermo. (2017). "Justicia y federalismo", Revista de la Facultad de Derecho de México, Tomo LXVII, (269), 475-517.

» Benente, Mauro y Ferrando Kozicki, Santiago. (2020). "Noticias de ayer. El COVID-19 en las prisiones. Novedad y catalización", en Altavilla, Cristian y Villegas, Candela, Los desafíos del Derecho frente a la Pandemia COVID-19. Mirada del Derecho Argentino con aportes del Derecho Comparado (pp. 37-44). Buenos Aires: IJ Editores / Universidad Siglo 21.

» Bidart Campos. Germán. (2018). Compendio de Derecho Constitucional. Buenos Aires: Ediar, 2018.

» Carnota, Walter F. (s.f.) La acción declarativa de certeza de la Vicepresidencia de la Nación y las enseñanzas del derecho constitucional comparado según la Cor- 
te Suprema (más allá del "caso"). En El Dial.com. Biblioteca Jurídica Online, disponible en: https://www.eldial.com/.

» Carnota, Walter y Maraniello, Patricio. (2008). Derecho Constitucional. Buenos Aires: La Ley.

» Gargarella, Roberto. (2014). La sala de máquinas de la Constitución. Dos siglos de constitucionalismo en América Latina (1810-2010). Buenos Aires: Katz Editores.

» Gelli, María Angélica. (2004). Constitución de la Nación Argentina. Comentada y Concordada. Buenos Aires: La Ley.

» Hernández, Antonio M. (2003). Las emergencias y el orden constitucional. México: UAM - Rubinzal-Culzoni.

» Hernández, Antonio M. (2020a). "La Emergencia por el Covid-19 en Argentina”, en González Martín, Nuria y Valadés, Diego (coord.) Emergencia Sanitaria por COVID-19. Derecho constitucional comparado (pp. 24-32). México: Universidad Nacional Autónoma de México, 2020

» Hernández, Antonio M. (2020b). Emergencias, orden constitucional y COVID-19 en Argentina. La Ley Online; AR/DOC/1352/2020.

» Jones, Mark. (1998). "Una evolución de la democracia presidencialista argentina: 1983-1995", en Mainwaring, Scott y Shugart, Matthew S. (comps.), Presidencialismo y democracia en América Latina (pp. 213-253). Buenos Aires: Paidós.

» Molinelli, Guillermo; Valeria, Palanza y Gisela, Sin. (1999). Congreso, presidencia y justicia en Argentina. Buenos Aires: Temas Grupo Editorial.

» Negretto, Gabriel L. (2013). Making Constitutions. Presidents, Parties and Institutional Choice in Latin America. Cambridge: Cambridge University Press.

» Quiroga Lavié, Humberto. (2009). Derecho Constitucional Argentino, Tomo II. Santa Fe: Rubinzal-Culzoni.

» Robles, Miguel. (2020). "El castigo en los tiempos del cólera", en Altavilla, Cristian y Villegas, Candela (Dirs.), Los desafíos del Derecho frente a la Pandemia COVID-19. Mirada del Derecho Argentino con aportes del Derecho Comparado (pp. 3136). Buenos Aires: IJ Editores / Universidad Siglo 21.

» Sabsay, Daniel A. (2020) "Coronavirus y Estado de Derecho en Argentina”, en González Martín, Nuria y Valadés, Diego (coord.) Emergencia Sanitaria por COVID-19. Derecho constitucional comparado (pp. 33- 41). México: Universidad Nacional Autónoma de México.

» Sagüés, Néstor Pedro. (2017). Manual de Derecho Constitucional. Buenos Aires: Astrea.

» Spisso, Rodolfo R. (2020). "Inconstitucional delegación de facultades legislativas en materia tributaria en la ley 27.541", en Comentarios a la ley de solidaridad social y reactivación productiva en el marco de la emergencia pública (pp. 43-49). Buenos Aires: La Ley. 